\title{
THE ACTUALITY OF THE HISTORY OF POLITICAL THOUGHT
}

Dick Howard*

\begin{abstract}
What is the essence of politics? How does one draw the line between politics and the political? How anti-political properties are said to be opposed to a supposedly political nature of human beings? The article offers original reflections and insights into the actuality of the history of political thought.

KEYWORDS - Anti-political. Government. Political theory. Politics. The political.
\end{abstract}

RESUMO - Qual é a essência da política? Como devemos diferenciar entre a política e o político? Como propriedades anti-políticas podem ser concebidas em oposição a uma natureza supostamente política dos seres humanos? O artigo oferece reflexões originais e instigantes sobre a atualidade da história do pensamento político.

PALAVRAS-CHAVE - Anti-político. Governo. O político. Política. Teoria política.

Although Aristotle's definition of man as a "political animal" has been repeated again and again during the two and a half millennia since the demise of Athenian democracy, most of us most of the time are quite happy to let others take responsibility for governing while we get on with our everyday lives. We may have opinions on how the government should govern, and we may have certain expectations about the kind of persons to whom we trust this responsibility. But these are personal, subjective, and private, expressed publicly (if at all) only on election day. when we more often than not vote against the other candidate rather than for our own. Politics has become a profession much like any other, with its specialized training, criteria of excellence and consumers to satisfy. Those of us who follow the goings-on among the political class of society tend to judge its practitioners in the same way that we evaluate the

* Distinguished Professor, State University of New York, Stony Brook. This paper was originally published in Globale Rekonfigurationen von Arbeitund Kommunikation. Festschrift für Hermann Schwengel, Voike Rehbein and Klaus-W. West (Eds.), Konstanz: UVK Verlagsgesellschaft, 2009, p. 241-254.

\begin{tabular}{|l|l|l|l|l|l|}
\hline Veritas & Porto Alegre & v. 55 & n. 1 & jan./abr. 2010 & p. $67-81$ \\
\hline
\end{tabular}


professional athletes or entertainers competing for popular admiration. We are aesthetes, concerned first and foremost with what interests us and only then with what affects our interests.

Perhaps the ancients were political animals; we moderns seem to have become anti-political beings. Yet, like them, we call our political institutions "democratic" and are proud of our democratic way of life. The fact that we criticize our politicians for poll-guided responses to problems, as if personal moral "character" is a better guide than the popular will, suggests that we doubt the wisdom of the people whose sovereignty we ritually affirm. Whether this passage from ancient political to modern anti-political democracy represents progress is questionable. But the clock cannot be turned backward; anti-politics has become the modern replacement for politics. Its implications need to be analyzed and the historical process by which it emerged need to be evaluated. The term itself suggests that anti-politics is nonetheless a kind of politics.

After the Fall of the Wall in 1989, followed by the dissolution of the Soviet Union in 1991, democracy seemed to be the only legitimate form of politics. Yet, nearly two decades later, doubt and skepticism have replaced optimism that accompanied the unexpected dissolution of the Cold War. "Democracy" was victorious, by default. In the former communist bloc, every step forward has been accompanied by two steps backward, as nationalism serves to compensate for the loss of the low-level but real economic security of the old order. Free elections there, as elsewhere, are now fruitful terrain for populist demagogs peddling nostalgia while blaming the West (meaning the United States, if not its "Jewish Lobby") for their difficulties. As in the $20^{\text {th }}$ century, when democracy gained its authority by contrast to its anti-political enemies (fascism, communism as well as unrestrained capitalism), in our $21^{\text {st }}$ century it shines only with a light reflected by new forms of anti-politics (fundamentalism, terrorism and economic globalization). The supporters of democracy have come to value it more for what it is not than for the vision of a shared future that it offers. But if its attractiveness has come to depend only on the negation of its anti-political enemies, democracy could well disappear in our new century. It is careless today to herald democracy's uncontested triumph. It would not be the first universally admired political system to disappear because its realization was taken for granted.

The messianic hopes with which George W. Bush led America into a futile, frustrating, and in every sense of the word costly adventure in the Middle East have been dashed. Mr. Bush may still believe, as he declared in his second inaugural speech, with "complete confidence in the eventual triumph of freedom... because freedom is the permanent 
hope of mankind, the hunger in dark places, the longing of the soul". But that faith is only the rhetorical expression of an anti-political democracy; it is metaphysics, or theology, rather than political thought. It does not follow, however, that America, and the world, would have been a better place if the Middle East had been left to fester under the despotic rule of self-perpetuating elites. The problem is that democracy is not a simple institutional arrangement, like the elections in the former Soviet bloc, that can be imported, let alone imposed on a nation. The American expectation that, once the old order was overthrown, the people would begin to govern themselves freely, is another illustration of the antipolitical assumptions that have come to dominate political thought in that country. Nonetheless, popular support for the invasion of Iraq - insofar as it was not simply an emotional reaction to September 11 2001 , or to the false claims about Iraqi weapons of mass destruction illustrates the fact that anti-politics is still a politics. Its specificity arises from the fact that its goal is the elimination of politics (which will be unnecessary after "the eventual triumph of freedom" heralds an earthly paradise). As such, anti-politics is a self-contradictory project, condemned to failure.

Anti-politics criticizes, and may attempt to overthrow, really existing democracy on the ground that it is the true realization of democracy. It claims that its success will insure the reign of peace and harmony; its political battles are a war to end all wars. In the $20^{\text {th }}$ century, anti-politics appeared in the phenomena of fascism, communism and unrestrained capitalism. As with the misguided war in Iraq, these movements must not be caricatured; the motives of their members could be well-intended. Fascism challenged the merely formal, divisive and weak-willed new democracies that emerged from the carnage of the first World War in the name of the will of a pure and united nation. In the place of the selfalienated individualism of bourgeois society, the fascists proposed to restore a pre-existing substratum of national homogeneity and ethnic destiny. Communism, for its part, denounced the exploitation of the working class that was hidden beneath the formal democratic equality of rights; the proletarian revolution would overcome class division, ushering in a unified society, replacing the anarchy of competitive capitalism by rational planning. As for pure capitalism, its political defenders criticized the short-term vision of those who used their democratically guaranteed vote and voice in support of government intervention into the workings of the free market, which is the only guarantor of true individual liberty. A truly free market capitalism, they argue, will create leisure time and cultural riches for all because citizens recognize the fact that the collective wisdom of the market is greater than the 
knowledge of any single, private individual. In this capitalist anti-political utopia, economics replaces politics, insuring private satisfactions that compensate for the loss of political participation, which was no longer necessary.

Each of these $20^{\text {th }}$ century movements was undeniably political. The faults of the newly democratic societies that they criticized were often real. In particular, they were reacting to the divisions introduced by the multitude of particular interests that gained equal voice in the new democratic institutions. They objected to the egoistic individualism that they claimed was unleashed by democracy; they denounced its secular civilization for promoting a relativism that left no room for universal values; and they blamed it for the domination of opinion over truth, emotion over science, and competition over community. But the remedies they prescribed would have eliminated the possibility of political action since a homogeneous nation, or a completely planned proletarian society, or a thoroughly market-regulated economy would have no need to seek popular legitimation for its decisions, no reason to deliberate before pronouncing judgement, and no means by which its rules and regulations could be contested or modified. In this sense, each was an anti-political politics. When fascism or communism did seize power, it became clear that this source of its strength is also the root of its weakness: because its unitary goals led it to over-reach, taking responsibility for the entirety of social and even personal relations, it was powerless in the face of the unexpected; responsible for everything, there was nothing to which it could appeal for support. Although each had external enemies, the regime collapsed under its own weight, undermined by the very monopoly that it had maintained. By comparison, it was the failure of capitalism to realize its anti-political goals that explains its continued existence. For the same reason, capitalism and democracy are often seen to be two, inseparable, sides of the same coin.

The early years of the $21^{\text {st }}$ century have witnessed the emergence of new forms of anti-politics in the forms of fundamentalism, terrorism and the critique of globalization. As with their $20^{\text {th }}$ century ancestors, each justifies itself as both a critique of and a remedy for the immanent failings of democracy. However, what makes these new forms of antipolitics different is that they are a response to the anti-political nature of the established Western democracies that, as in the case of George W. Bush, are incapable of reflecting on the implications of their own political projects. These anti-political democracies are unable to recognize that religious fundamentalism might be a legitimate attempt to reassert human dignity in the face of the moral relativism produced by a privatized individualism that can find no grounds to condemn sexual license and 
rampant consumerist hedonism. Complacent democrats fail to ask themselves whether terrorism might be a reply to their own moralizing political culture that refuses to recognize any values foreign to its own; they justify their anti-politics as a legitimate response on the part of a minority to the uncomprehending pressure of an oppressive civilization that refuses to recognize the right to be different. Similarly, self-sure democrats do not see that an economic world without borders in which cash-value has become the only value is not the inevitable result of the freedom that they identify with private liberty. What they praise as globalization appears to others as the expression of an economic imperialism. But, tout comprendre n'est pas tout pardoner: $21^{\text {st }}$ century anti-politics is no more acceptable than was its predecessor. Indeed, it is more dangerous insofar as it is a reaction to an anti-political democracy that is not capable of putting itself, and its values, into question. It was this ability, whose basis was not its economic productivity but its roots in the soil of the Western democratic tradition, that explains the survival of $20^{\text {th }}$ century democratic capitalism.

If democracy is to survive the continued assaults of the new antipolitics of the $21^{\text {st }}$ century, it will have to rediscover its own historical foundations. If it remains a form of anti-politics, it might well imitate its $20^{\text {th }}$ century predecessors, collapsing from within rather than from the force of its anti-political enemies. The foundation for this reconsideration of the nature of modern democracy was present already in the challenge of $20^{\text {th }}$ century anti-politics; it has been renewed by the new threats of our new century. The anti-political temptation that privileges the values of unity over diversity, rationality over opinion, universality over particularity, community over competition, the sacred over the secular, stability over innovation and tradition over novelty has to be understood as a internal challenge rather than an external threat. Because these anti-political values are immanent, they are a warning against the complacency of anti-political democrats who think that democracy can be achieved once-and-for-all, forgetting that there is no democracy without democrats. The challenge posed by anti-politics prevents the self-satisfied illusion that democratic political decisions are, or ought to be, identical with the will of society, reminding the citizen that there must always exist a tension between the two equally important levels on which individuals in a democracy live their lives. Democratic political power is legitimate only when it can be, and is, contested by the society that it claims to govern. The travails of modern democracy in the face of the ever-renewed anti-political temptation reveal the more general structure of politics, whose history in turn casts light on the possibilities for democratic renewal in the $21^{\text {st }}$ century. 
I have been talking about politics without defining the term because at one level we all know what it means. But if anti-politics is itself a form of politics, as the examples given above suggest, "politics" cannot be understood simply as the action of governments or those seeking to control them (since anti-politics seeks to overthrow the existing regime). To identify politics with the activity of politicians in their competition for power would be tautological. At the other extreme, it would be a crude simplification to reduce politics to Lenin's famous definition kto kogo ("who whom," i.e., who does what to whom). Power is certainly involved in politics; but power is not identical with force, which is imposed on citizens without their consent. This distinction suggests that power should be defined as legitimate force. It is a type of authority to which members of a society implicitly or explicitly consent. The source of legitimate power or authority will differ in different societies; it may be secular or sacred, rational or customary, institutional or charismatic; its basis may be strength, knowledge, or wealth, each of which will in turn be defined differently in different historical contexts. It follows that "politics" is the creation of the meaningful discourse and shared values through which force acquires legitimate authority. The history of political thought is the story of the search for legitimacy and the clash among the forms of legitimacy.

This conception of politics does not neglect the material stakes at issue in the quest for power; but it avoids the skeptical reduction of politics to competing interests. The material interests that seek satisfaction in the political arena can be understood as practicing a kind of anti-politics that challenges the established order. For example, in the case of $20^{\text {th }}$ century capitalism, the reality of exploitation and domination that were hidden and ignored by the identification of freedom with free markets produced a social movement for change. Supporters of the existing political order saw its claims as anti-political, calling them "socialist." But the result of its pressure was the welfare-state measures adopted by the New Deal, which prevented democratic capitalist society from adopting the antipolitical form of a pure market economy. Market capitalist anti-politics was kept in its proper place; its critical function within a democratic society was recognized, since markets do play a regulating role in a democratic society. The danger is that they become an external challenge to democracy itself. This balance between politics and anti-politics was in part the result of a battle of ideas; but the material conditions that created a powerful social movement, as well as the political genius of Franklin Roosevelt, cannot be neglected. While a deeper analysis of this uniquely American history is beyond the scope of this essay, it will be necessary here to refer often to the hard realities of history in order 
to understand the development of the political thought that is being analyzed here. ${ }^{1}$

If politics and anti-politics both compete with one another, supplement each other, and are sometimes transformed into their opposite, this is due to the fact that both of them are attempts to establish legitimate political authority. Politics exists in every society; without it, men and women who co-exist in a given space and time would be no different than a queue of passengers waiting for a bus, or consumers bustling around a shopping mall searching for the best bargains. Just as the members of an athletic team are joined together by a common goal or "team spirit" that transcends their particular and private concerns while giving to each a new and shared identity, so too are the citizens of a society joined together by a shared framework of meaning and values that unites them in spite of their private differences. People may belong to many social organizations, each of which is defined by the goals that it seeks. Political organization is the highest of these institutions because it organizes the relations among all the other, less inclusive groups, establishing a hierarchy of values that can always, in principle, be challenged and changed if it loses its ability to unify (becoming an anti-politics) or if the excluded come to recognize their own force (as anti-political) and transform the previous value-system. ${ }^{2}$

The shared framework of meaning and values that unites the members of a society can be defined as "the political." This general term is not as abstract as it may appear. The political delineates the lines between the licit and the illicit, the just and the unjust, the knowable and the unknown. It defines the grammar and the syntax that govern the social interactions among members of a given society. Just as there are some things that cannot be said, some expressions that cannot be understood, and even some sounds that cannot become words, so too in any society

1 Historical illustrations of this dynamic by which anti-politics that represents excluded material interests challenges a politics that has itself frozen into an anti-politics will recur frequently in this book. The first of these is offered in Plato's Republic when the Sophist, Thrasymachus, argues that justice is simply that which serves the interest of the strong. To be sure, Plato disagrees, as will be seen; but the fact that he finds it necessary to integrate the argument of the Sophist points to the fact that that anti-politics has a legitimate and necessary task: it challenges the gap between the claims of the established forms of authority and the real social relations that they serve to legitimate.

2 The fiercely capitalist British Prime Minister, Margaret Thatcher, famously replied to the critics who insisted that she take into account the good of society that "there is no such thing as society; there are only individual men and women and there are families." In a sense, she was right; "society" is not something that exists in a state of nature, without human intervention. It is politics that makes society - or in Mrs. Thatcher's case: anti-politics. 
there are things that cannot be done, actions in which no one will join, and projects that no one could imagine. If the symbolic universe of a given people is defined by its religious beliefs, this will produce types of behavior that - to the outside observer - are incomprehensible, foolhardy, or irrational; but for the same reason, the believers will be incapable of understanding the "anti-religious" objections of the critical observer. The dialogue of the deaf cannot perdure indefinitely if the religious and the secular are to inhabit a common political world.

An well-known example that changed the course of political history can be introduced briefly to concretize the way in which the political provides a framework within which politics and anti-politics compete. For long centuries of Western history, the political was defined by religious belief. That same belief became an anti-political force instituting a new definition of the political when the Protestant Reformation challenged the Catholic emphasis on external forms of worship. The Protestants denied that the Catholic sacramental practices were the proper realization of the divine will; but the subjective faith and inscrutable divine grace on which their new religion was based prepared the way for a secular individualism which would become the new defining principle of political life. An anti-politics became the basis for a new but still religiously founded politics, only to be confronted in turn by a new, secular anti-politics that established finally the basis of our modern individualist political culture. The fact that the anti-political challenge develops within the existing political forms - Protestantism is still based in Christianity, secular individualism builds from the Protestant stress on the direct relation of the believer to his God - points to a structure that is repeated constantly in political history. The reason for this lies in the fact that while the political defines the type of politics that can undertaken in a given society - in this case a religiously based action - politics is also a constant attempt to define the political. It may conserve the existing understanding of the political but it may also, and perhaps unintentionally, inaugurate a new vision, as did the Reformation. ${ }^{3}$

The unique role of the political can be illustrated by comparing a philosophical understanding of the political with the type of analysis

3 There is a further dimension of the political that needs to be clarified. It was suggested already by the idea that religion could be a form of the political. The political is not identical with politics as it is practiced in our modern societies, or as it is defined by political science, where political life is distinguished from other facets of social life by its governmental function. Political power need not be exercised by means of recognizably political institutions. Women were not wrong to denounce the patriarchy, socialists to refuse the dictatorship of capital, nor rationalists to criticize an unholy coalition of church and state. 
offered by political science. The scientist looks at his object of study from outside, as if he were using a telescope or a microscope to study something that is unaffected by his regard. Differences among individuals and groups exist in every society; some of these qualities are natural, others are cultural. Differences of economic wealth, social status, political power can be described; ethnicity, gender, religion or education are then charted and correlated. In the case of politics, the difficulty is to determine which of these differences makes a difference from the standpoint of the participants. Which one could lead a person to complain about the injustice of her lot and expect others to understand and act on the grievance? Why are some social differences considered licit? When are the forms of inequality treated as the accidental result of unknowable factors? This is where the philosophical reflection on the nature of the political becomes important, since it defines the licit, the just and the knowable, as well as their opposites. It establishes the shared background against which differences become salient. The idea that the strongest, or the richest, or the most virtuous - or the people as a whole - should rule reflects a political choice which creates the shared background. Similarly, the unthinking application of the economic theory of "rational choice" to all aspects of behavior in contemporary society is itself a political decision about how to understand and organize the social and private worlds of the citizenry. This political dimension is hidden by the scientific illusion that a neutral observer is merely defining the facts as they exist. By underlining the dimension of choice that is involved, the philosopher makes clear that "the political" is not imposed on a society from above or beyond its boundaries.

At this point, the basic problem of all politics can be defined. The political is distinct from the society that it structures; and yet its legitimacy, which distinguishes power from force, depends on its being perceived by the members of the society as the expression of their own will. That is why consent is fundamental to politics. But how can the participants consent to be governed by a power that is distinct from them and external to their own will? This is the point at which the theoretical distinction of politics and anti-politics acquires its practical importance. Politics accepts the difference between the two levels; it realizes that it can only exist because the political is distinct from other types of social relations. But it recognizes also the need for politics to earn the consent of the members of the society it governs. Politics can accept diversity, plurality and particularity because it is aware that it is different from these relations. Anti-politics reacts to the need for the consent of the governed by seeking to create relations of homogeneity, unity and universality among the members. In doing so, anti-politics correctly recognizes that a 
society founded on difference cannot long exist as a society; in this way, anti-politics serves again as a complement and corrective to politics. The danger, however, is that anti-politics goes further, eliminating the autonomy of the political by claiming that it has (or will, should, or can) overcome the constitutive difference that made politics possible. Such a realization of politics would return humanity to a pre-political state of nature that would have no need for politics. It would be literally anarchic: an arche, without rule.

The challenge of politics is to preserve the distinction between the political and the society that it institutes while at the same time avoiding the complete separation of the two poles, which would also introduce a form of anti-politics. This is necessary because the complete subordination of society to the political values that make it what it is would destroy the possibility of free consent by the members while ruling out any possible change that might be advisable in the face of newly recognized conditions. On the other hand, the complete subordination of the political to the actually existing social relations would freeze the imagination of the members, blinding them to the need to recognize the new and to face up to its challenge. But some subordination must exist if the difference between the two spheres is not to become absolute; the gap cannot become a chasm, the distinction an opposition, the relation a separation. How can difference be maintained while unity is preserved? How do the many become one without abandoning their diversity? How can the freedom of the individual be protected while the equality of membership is maintained?

These theoretical questions return us to the problems of democratic politics. Democracy is a form of rule (kratos) by the people (demos). It appears at first that this rule by the people over itself eliminates the constitutive difference between the political and the social. Self-rule implies autonomy, which comes from the Greek terms autos (self) and nomos (law). But laws govern the relations among those subject to them; the concept of ruling remains ${ }^{4}$. The difference of the people governing themselves and the people as governed (by themselves) is not eliminated in a democracy. The citizen as elector or juror is acting as a ruler making decisions that will apply to him and his fellows as, for example, an economic actor, the participant in a lawsuit, or a family member. What is more, it is the majority that rules in a democracy, leaving the minority unsatisfied by its decisions. But, it is important to remember that in a functioning democracy, the minority does not refuse to accept the

4 This is clear when it is recalled that the Greeks distinguished between the laws of nature (physis) and a conventional or human law (nomos). 
verdict of its peers; instead, it sets about organizing itself in order to become in turn the majority. ${ }^{5}$ The reason for this acceptance is that all of the participants accept the political framework that makes possible democratic politics. The shared conception of the political explains why citizens accept the authority of the elected rulers of the moment as long as their power depends on the consent of the governed.

This fundamental principle of democracy is not self-evident. One of the lessons taught by the study of the history of political thought is that the source of the legitimation that distinguishes power and authority from sheer force has always been outside and external to the members of society, in the form of gods or God, nature or natural law, tradition or reason. Democracy's uniqueness lies in the fact that the source of legitimacy is immanent to politics. The result is paradoxical: the consent of the governed and the elimination of the constitutive distinction of the political from the social seem to go together. The non-democratic forms that predominate in the history of political thought apparently preserve the difference between the two levels, whose relation they at the same time maintain. God remains divine even while the secular world is affected by the sacred presence; natural law is nowhere fully realized in the existing world which nonetheless strives to conform to it; and reason remains an ideal that is sought even though human finitude makes its realization impossible. It is this difference that makes possible a kind of criticism of the existing realization of the political that does not put its basic structure into question. Political reform becomes possible in this manner. But the reformers may meet unexpected resistance; to overcome it, they must first understand and interpret it; and in so doing, they begin to alter their vision of the shared concept of the political. That is how the movement for reform of the Catholic church became the Reformation.

The case of democracy is complicated by the fact that the immanence of the democratic principle of consent means that the principle of the political and the actual practice by which decisions are made are not distinct but rather are identified. This has potentially anti-political consequences insofar as the formal principle of consent is treated as the real imperative that every member of the society truly and actual give her consent at every moment to every decision while participating fully and completely in the political life of society. The result would be the kind of

5 It may refuse, arguing that the democratic institutions have been perverted, that the decision reflected a merely formal equality of participation that was overshadowed by the great wealth, or control of the means of communication, or the abuse of governmental power. In this case, it would denounce the merely formal democracy and seek to create a real or realized democracy. But the danger here is that a legitimate criticism of abuses of democracy becomes an anti-politics. 
anti-politics that threatened the new democracies of the $20^{\text {th }}$ century. The strength of democracy that comes from the immanence of its foundational principle becomes the source of its potential weakness. If the citizen must be consulted on each and every decision concerning all aspects of societal life, the result would not only be chaos and confusion; it would mean also the destruction of political life, which can be maintained only insofar as its autonomy is insured. As Rousseau said famously, a true democracy would be possible only for a society of angels. And, he added elsewhere, if men were angels, there would be no need for government. A perfectly just society would have no room for and no need of politics.

The paradoxical potentiality of democracy to take an anti-political turn reveals in turn the potentiality of all forms of political society to adopt anti-political means of action. After all, the democratic form of antipolitics leads to the positive demand that the merely formal principle of consent be given real force. That is why democracy is the generic form of politics. The apparent separation of the sources of social legitimacy in non-democratic societies can come to be felt as a real alienation from the grounds of meaningful social relations. Attempts are then made to transcend the difference, overcoming the distance, realizing the governing principle of social relations. The anti-politics that then emerges is more difficult to recognize because it does not adopt a form that is easily seen as political. The example of the Protestant Reformation can again be used as an illustration. Luther's principles of sola fides and sola scriptura rejected the Catholic understanding of the sacramental role of the church because it concentrated only on the external practice of the faith. Luther's intention was not political; but the resulting redefinition of the political was seized upon by pious peasants who took the reformer at his word and sought to live according to the Word, unleashing a rebellion that was suppressed in blood. The positive implication of this anti-political aspect of the Reformation was that Luther recognized the need to create an autonomous Protestant church with its defined doctrine and practices.

The unity of the history of political thought is suggested by this interplay of the political, politics and anti-politics. The political can take many forms; looked at with a telescope, it can change with surprising rapidity; seen with a microscope, it is in constant movement. It is tempting to try to describe the process by applying the notion of a "paradigm" that Thomas Kuhn applied brilliantly in his massively influential study of The Structure of Scientific Revolutions (1966). What Kuhn calls "normal science" works in terms of an established paradigm that sets out the assumptions of the disciplines and the parameters for research. As the 
scientists continue to probe the implications of the paradigm of normal science, the encounter abnormalities, results that don't fit with the expectations or that positively contradict them. At first, researchers will invent additional hypotheses in order to adapt the abnormalities to the existing paradigm. But exceptions will continue to be discovered, unease will pervade the community of investigators, until someone proposes a new paradigm that, swiftly, as if everyone were waiting for the new theory that reorganizes the field, establishes itself as the new basis of normal science. This vision of historical change is suggestive, but only from the point of view of science. As was seen earlier, political thought has to take into account not only the historical facts that fall to its purview but also the way in which these facts are experienced by the participants in the political world. That is why the anti-political temptation has no analogue in the history of science, whereas its role in political thought is fundamental, and cannot be reduced to the emergence of a mere anomaly.

The political defines the framework within which legitimate politics in a given society can be carried out. But it is necessary to warn against oversimplification; "the" political cannot be reduced to one single, simple and singular principle; life is not so neat and tidy. What counts as "legitimate politics" need not have a form that would be recognized by a political scientist. Politics is the way in which the members of a society regulate their relations to one another (a process that includes understanding their debt to their ancestors as well as their responsibility to future generations). Religion is obviously a candidate for the definition of the political and the framework governing legitimate political action; but there are many others, beginning with the Greek quest to forge philosophical truth against a background of chaos, continuing in the Roman vision of a republic founded on the co-existence of manly virtue and legal equality, which was renewed by Machiavelli. And the definition of the political need not concern only the public sphere; legitimate relations among citizens can be determined by shared private selfunderstanding, as in the Hellenistic philosophies such as Stoicism that emerged after the demise of Athenian democracy, or in the early Christian religion of personal, charitable love, which reappears regularly within the institutional framework of the Roman Church. With the onset of modernity with its principle of individuality and its stress on the experience of the subject, the picture is complicated still further. The point to be made here at the outset of our study is that "the political" is constantly enriched and overlaid with strata of meaning; and yet, the simple schema defined at the outset remains valid, however thickly woven the web of signification. The challenge is always to define the political. 
Because of the difference between politics and the political, there will be always present the need for anti-politics to prevent both the abusive unification of the political principle and its realization and their radical separation. As with the definition of the political, forms of antipolitics can overlap; what was a legitimate form of politics can become an anti-politics when the definition of the political changes. The Greek Sophists who were the allies of Pericles at the time of Athens' glory are the butt of Plato's critique; the legalism of republican Rome provided an instrument for rule over the vast empire that it acquired; and the simple humanity of Christianity became not only an institutional Church but the source of legitimacy for the Holy Roman Empire. Privatized forms of anti-politics emerged as well, first with the Stoic withdrawal, then with the monastic forms of Christianity, and forward to the humanism of the Renaissance. None of these moments, or the others that will be encountered, was fated to remain as a simple movement of opposition to the established definition of politics. They might appear as the rejection of the existent order; but as anti-politics their political significance cannot be ignored. Indeed, the appearance of forms of anti-politics is a sign that the prevailing sense of the political is losing its grip; the tension between the political and the society whose relations it regulates is weakened, the separation may have grown too great, or a process of fusion has begun - or, indeed, the two processes can be occurring at one and the same time, separation encouraging a demand for fusion, fusion calling forth a new type of distinction. And, as was seen in the case of the $20^{\text {th }}$ century forms of anti-politics, different forms of the reaction to the weakening of the political can coexist.

I began this series of reflections by pointing out that $20^{\text {th }}$ century democracy is threatened by anti-politics, whose nature I tried to illustrate with contemporary examples. I have now outlined the broad theoretical structure that explains that anti-politics is not an aberration but rather an essential component of the way in which politics works and has always worked. It was precisely the analysis of democracy that showed why anti-politics remains a permanent feature of all political societies - and why all societies are political, even when their political nature remains implicit. The renewal of democracy in the $21^{\text {st }}$ century has to build from this structure. It cannot simply rebuild on the basis of the older models; times have changed, conditions are different, the challenge is to recognize the new for what it is, rather than to let it sink back into the familiar patterns. $21^{\text {st }}$ century democracy will share some features with $20^{\text {th }}$ century democracy, just as the latter built on ideas and practices developed in Athens, Rome and Florence. But of course the new cannot 
be predicted on the basis of history. What history does teach, however, is what must be avoided in order to make possible the recognition of the new when it presents itself.

The reason to study the history of political thought is not to look for models, be they positive or negative. Rather, over the broad sweep of history, certain structural features come to be identified even while their actualization differs as conditions vary and times change. Once it is seen that democracy represents the generic form of politics, it becomes possible to recognize its features in the various political species that have been invented by human societies. This is not to say that there is a democratic "spirit" that is always present in political history, awaiting only the kiss of its philosophical Prince Charming to awaken from its dogmatic slumber. But there is always present a vision of the political, which does need to be revived if the interplay of politics and anti-politics is not to result in a mutual negation of the one by the other. That is what needs to be rekindled in our new century if we are to renew our democracies. Defining the political today means also renewing it. 